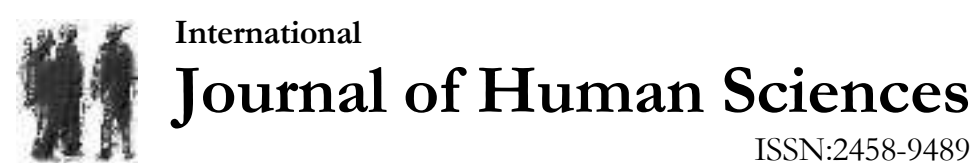

Volume 16 Issue 4 Year: 2019

\section{Ways of communication between trainers and parents ${ }^{1}$}

\author{
Yeşim Gök ${ }^{2}$ \\ Güçlü Özen ${ }^{3}$
}

\begin{abstract}
The aim of this study is to determine the ways in which the coaches who work in different branches communicate with parents and to determine the importance and importance of using these communication paths in terms of different variables. The study population is the same as the sample of the study and consists of 70 (41 Male 29 Female) coaches (permanent, contracted) who work in Izmir.In this research, cross-sectional approach is adopted from general survey models. The data were collected by Coşkun (2010) by means of scale form $m$ Parent-Teacher Communication Paths ", which was conducted for validity and reliability. The scale is 5-point Likert, consisted of 47 items of behavior and eight sub-dimensions aiming to measure the level of care and realization of communication with parents.

As the data were normally distributed and $n>30$, dependent t-test was used to compare the level of care with the parents, but the sub-groups were $n<30$ and non-parametric tests were preferred for the evaluation of other independent variables. The Kruskal-Wallis test was conducted for Mann Whitney-U, education and coaching level independent variables.

As a result of the analyzes, a statistically significant difference was found in all sub-scales and total scores between the level of care of the coaches and the way of communication with parents $(p<0.05)$. In the case of caregivers of parents with regard to the ways of communicating with parents, in the sub-dimension of socio-cultural activities in terms of gender argument, in the parent visit sub-dimension in terms of the educational level argument, in terms of the instructorlevel argument, in the sub-dimensions of telephone-internet, parent visits, information-informing there was a significant difference $(\mathrm{p}<0.05)$.

In terms of gender independent variables, there is a statistically significant difference between the sub-dimensions of telephone-internet, parent visits, home visits sub-dimensions, cooperative level, and telephone-internet and parent visits $(\mathrm{p}<0.05)$.

According to these results, it can be said that the coaches cannot perform as much as the value attributed to the parents. In addition, it can be said that women are more concerned with socio-cultural activities than the ways of communication, the group with low level of education gives more importance to parents' meetings, while those with high levels of coaching tend to pay more attention to telephone, parent visits and informing-informing ways. In terms of the phenomenon of conducting communication paths, it is observed that males are better in telephone-internet, parental hierarchy and home-visit. It has also been found that telephoneinternet and parent meeting paths are better performed as the seniority of coaching increases.
\end{abstract}

Keywords: Coach, parents, communication, sportsman.

\footnotetext{
1 This study was presented as Oral Presentation at the 2nd World Congress of Sport Sciences Research.

2 Graduate Student, University of Izmir Demokrasi , Institute of Health Sciences, vsmgok@hotmail.com

${ }^{3}$ Assoc. Prof., Izmir Demokrasi University, Department of Sport Science, guclu1234@yahoo.com
} 


\section{Introduction}

When the literature is reviewed, it is seen that the participation of parents in education has become increasingly accepted in education. The most important aim of the educational activities is to educate the children who are the future of a country as good people and good citizens. Factors such as school, family, environment, teacher and trainer play an important role in realizing these goals (Kolay, 2004). Researches conducted at home and abroad show that it is possible to increase the success of the student in school and sport and to be a good citizen through family, school and environment cooperation (Çalık, 2007).

Sports is an important activity in terms of the physical, spiritual and social development of a child. From the psychological and sociological point of view, it is stated that sports in childhood should be composed of studies in the form of games which will help the development of physical capacity, provide self-confidence, abide by rules and teach respect for the rights of others by taking into consideration the physical characteristics and spiritual structure of the child (Çamliyer, 1997).

The child experiences the greatest interaction within his family. The values gained in the family for the child's perspective are very important. The importance and place of human relations in human life cannot be underestimated as they cannot be denied. Mankind develops and realizes itself within the network of psychological and social relations it establishes (Ersanl1, 1989) The role of educated parents in adapting the child to sport cannot be denied.

Considering the effect of the family on the child, one of the most important factors on the bridge to be established with the child is effective parent-coach cooperation. Communication, which is defined as the process of transferring information from one person or group to another person or group, has an important place in the education-teaching process (Tutar, 2003). Many studies on the subject show that positive coach, parent communication and cooperation contribute to the academic success of students (Yiğit, 2009). In the literature, it is emphasized that family participation improves children's learning experiences and academic achievements (Lawson, 2003). Ludwig (1991) emphasizes the importance of informing families about studies and practices at school. If parents know what to do in school, and what they are expected from them and students, and they feel that they can help their children better and are more compatible with the teacher's teaching approach and behavior, they could to develop a family cooperation with the school. It means learning at home experiences are integrated all of education process in school (cited in Güven ve Güven, 2002). The necessity of cooperation between the school and the family to ensure the integrity and continuity of education (Ceyhan, 2008) is valid in sports training involving similar processes. In other words, a parallelism between sports hall and home life can be achieved. The purpose of this study is to determine the ways in which coaches communicate with parents and to determine their level of care and fulfillment in using these means of communication.

\section{Method}

\section{Data collection tool}

In the research, a cross-sectional approach was adopted from the general survey models. Data were collected by survey method. The data were collected by Coşkun (2010) by means of scale form The Ways of Communication of With Parents of Primary School, which was conducted for validity and reliability. The scale is 5-point Likert, consisted of 47 items of behavior and eight subdimensions aiming to measure the level of importance and performing of communication with parents.

\section{Research Group}

The study population is the same as the sample of the study and consists of 70 (41 Male 29 Female) coaches (permanent, contracted) who work in the school in Izmir.

\section{Data Analysis}

Because of $n<30$ in subgroups of indepented variables non-parametric tests (Mann Whitney$\mathrm{U}$ and Kruskall Wallis) were used for statistical analysis. 
Gök, Y., \& Özen, G., (2019). Ways of communication between trainers and parents, Journal of Human Sciences, 16(4), 1207-1216. doi:10.14687/jhs.v16i4.5752

In the pilot application of the scale, Cronbach Alpha internal consistency coefficient was found as 0,92 for the whole scale. In the original application, the internal consistency coefficients were found to be between 0.84 and 0.93 .

\section{Findings}

In this section the findings are presented separately as important and performing levels of communication way. The difference between the scale scores of the gender independent variables was evaluated with the Mann Whitney-U test and the results are given in Table 1.

Table 1: Mann Whithney-U test table in terms of gender variables (level of importance)

\begin{tabular}{|c|c|c|c|c|}
\hline Gender & & $\mathbf{N}$ & Mean Rank & $\bar{Z}$ \\
\hline \multirow[t]{2}{*}{ Face to face } & Man & 41 & 33,80 & \multirow{2}{*}{,- 84} \\
\hline & Woman & 29 & 37,90 & \\
\hline \multirow[t]{2}{*}{ Telephone } & Man & 41 & 38,01 & \multirow{2}{*}{$-1,23$} \\
\hline & Woman & 29 & 31,95 & \\
\hline \multirow[t]{2}{*}{ Correspondence } & Man & 41 & 33,57 & \multirow{2}{*}{,- 94} \\
\hline & Woman & 29 & 38,22 & \\
\hline \multirow[t]{2}{*}{ Visiting parents } & Man & 41 & 38,34 & \multirow{2}{*}{$-1,40$} \\
\hline & Woman & 29 & 31,48 & \\
\hline \multirow[t]{2}{*}{ İnformed that } & Man & 41 & 35,10 & \multirow{2}{*}{,- 20} \\
\hline & Woman & 29 & 36,07 & \\
\hline \multirow[t]{2}{*}{ Socialization } & Man & 41 & 31,38 & \multirow{2}{*}{$-2,02 *$} \\
\hline & Woman & 29 & 41,33 & \\
\hline \multirow[t]{2}{*}{ Parent meeting } & Man & 41 & 34,21 & \multirow{2}{*}{,- 63} \\
\hline & Woman & 29 & 37,33 & \\
\hline \multirow[t]{2}{*}{ Home Visit } & Man & 41 & 37,23 & \multirow{2}{*}{,- 85} \\
\hline & Woman & 29 & 33,05 & \\
\hline \multirow[t]{2}{*}{ Total } & Man & 41 & 33,90 & \multirow{2}{*}{,- 78} \\
\hline & Woman & 29 & 37,76 & \\
\hline
\end{tabular}

When the scale scores were examined in terms of gender independent variables, a statistically significant difference was found in the socio-cultural sub-dimension $(\mathrm{p}<0.05)$. When the averages are examined, it seems to focus more on socio-cultural activities.

The difference between the scale scores and the level of care for the education independent variables were examined by Kruskal Wallis test and the results are given in Table 2.

Table 2: Kruskal Wallies test table in terms of education variables (level of importance)

\begin{tabular}{|c|c|c|c|c|}
\hline \multicolumn{2}{|c|}{ Education } & \multirow{2}{*}{$\begin{array}{c}\mathbf{N} \\
5\end{array}$} & \multirow{2}{*}{$\begin{array}{c}\text { Mean Rank } \\
54,20\end{array}$} & \multirow[t]{2}{*}{ Ki Square } \\
\hline Face to face & High school & & & \\
\hline & License & 51 & 34,36 & 4,73 \\
\hline & Graduate & 14 & 32,96 & \\
\hline \multirow[t]{3}{*}{ Telephone } & High school & 5 & 42,80 & \\
\hline & License & 51 & 35,32 & 0,78 \\
\hline & Graduate & 14 & 33,54 & \\
\hline \multirow[t]{3}{*}{ Correspondence } & High school & 5 & 48,60 & \\
\hline & License & 51 & 33,48 & 2,82 \\
\hline & Graduate & 14 & 38,18 & \\
\hline \multirow[t]{3}{*}{ Visiting parents } & High school & 5 & 60,80 & \\
\hline & License & 51 & 33,52 & $8,48^{*}$ \\
\hline & Graduate & 14 & 33,68 & \\
\hline \multirow[t]{3}{*}{ Home Visit } & High school & 5 & 23,50 & \\
\hline & License & 51 & 37,22 & 2,26 \\
\hline & Graduate & 14 & 33,54 & \\
\hline \multirow[t]{3}{*}{ Parent meeting } & High school & 5 & 46,10 & \\
\hline & License & 51 & 34,30 & 1,56 \\
\hline & Graduate & 14 & 36,07 & \\
\hline
\end{tabular}


Gök, Y., \& Özen, G., (2019). Ways of communication between trainers and parents, Journal of Human Sciences, 16(4), 1207-1216. doi:10.14687/ihs.v16i4.5752

\begin{tabular}{llccc} 
Informed that & High school & 5 & 48,90 & 2,60 \\
& License & 51 & 34,94 & 32,75 \\
Socialization & Graduate & 14 & 51,00 & 5,31 \\
& High school & 5 & 36,25 & 3,99 \\
Total & License & 51 & 27,25 & 52,70 \\
& Graduate & 14 & 34,68 & 32,36 \\
\hline$*_{\mathrm{p}<0.05}$ & High school & 5 & 51 &
\end{tabular}

When the scale scores were examined in terms of the fact that education was independent, a statistically significant difference was found in parent visits sub-dimension $(\mathrm{p}<0.05)$. Looking at the averages, it is seen that the high school graduates pay more attention to their parents' visits. In order to determine the difference between groups, Mann Whitney-U test was preferred in paired comparisons. As a result of the analyzes, it is seen that the difference is between high school, undergraduate and high school graduate students.

The difference between the scale scores of the level of coaching was examined by Kruskal Wallis test and the results are given in Table 3.

Table 3: Kruskal Wallies test table in terms of coaching level (level of importance)

\begin{tabular}{|c|c|c|c|c|}
\hline Coach seniority & & $\mathbf{N}$ & Mean Rank & Ki Square \\
\hline \multirow[t]{5}{*}{ Face to face } & 1.level & 7 & 40,64 & \\
\hline & 2.level & 27 & 33,91 & \\
\hline & 3.level & 26 & 37,96 & 1,98 \\
\hline & 4.level & 6 & 31,83 & \\
\hline & 5.level & 4 & 26,75 & \\
\hline \multirow[t]{5}{*}{ Telephone } & 1.level & 7 & 23,29 & \\
\hline & 2.level & 27 & 32,28 & \\
\hline & 3.level & 26 & 34,15 & $13,90^{*}$ \\
\hline & 4.level & 6 & 55,42 & \\
\hline & 5.level & 4 & 57,50 & \\
\hline \multirow[t]{5}{*}{ Correspondence } & 1.level & 7 & 33,86 & \\
\hline & 2.level & 27 & 37,44 & \\
\hline & 3.level & 26 & 34,98 & 2,96 \\
\hline & 4.level & 6 & 41,00 & \\
\hline & 5.level & 4 & 20,38 & \\
\hline \multirow{5}{*}{ Visiting parents } & 1.level & 7 & 40,93 & \\
\hline & 2.level & 27 & 30,15 & \\
\hline & 3.level & 26 & 33,13 & $10,19 *$ \\
\hline & 4.level & 6 & 55,92 & \\
\hline & 5.level & 4 & 46,88 & \\
\hline \multirow[t]{5}{*}{ Home Visit } & 1.level & 7 & 41,50 & \\
\hline & 2.level & 27 & 35,78 & \\
\hline & 3.level & 26 & 35,21 & 6,68 \\
\hline & 4.level & 6 & 18,92 & \\
\hline & 5.level & 4 & 49,88 & \\
\hline \multirow[t]{5}{*}{ Parent meeting } & 1.level & 7 & 25,64 & \\
\hline & 2.level & 27 & 33,06 & \\
\hline & 3.level & 26 & 35,79 & 6,12 \\
\hline & 4.level & 6 & 49,58 & \\
\hline & 5.level & 4 & 46,25 & \\
\hline \multirow[t]{5}{*}{ İnformed that } & 1.level & 7 & 34,21 & \\
\hline & 2.level & 27 & 29,33 & \\
\hline & 3.level & 26 & 36,15 & $9,40 *$ \\
\hline & 4.level & 6 & 54,17 & \\
\hline & 5.level & 4 & 47,13 & \\
\hline Socialization & 1.level & 7 & 28,36 & 3,27 \\
\hline
\end{tabular}


Gök, Y., \& Özen, G., (2019). Ways of communication between trainers and parents, Journal of Human Sciences, 16(4), 1207-1216. doi:10.14687/ihs.v16i4.5752

\begin{tabular}{|c|c|c|c|c|}
\hline \multirow{9}{*}{ Total } & 2.level & 27 & 39,09 & \multirow{9}{*}{2,21} \\
\hline & 3.level & 26 & 32,75 & \\
\hline & 4.level & 6 & 43,00 & \\
\hline & 5.level & 4 & 30,38 & \\
\hline & 1.level & 7 & 34,50 & \\
\hline & 2.level & 27 & 34,94 & \\
\hline & 3.level & 26 & 34,52 & \\
\hline & 4.level & 6 & 46,83 & \\
\hline & 5.level & 4 & 30,38 & \\
\hline
\end{tabular}

When the scale scores were examined in terms of the fact that the level of coaching was independent, it was found that there was a statistically significant difference in telephone / internet, parent visits and information sub-dimensions $(\mathrm{p}<0.05)$. In order to determine the difference between groups, Mann Whitney- $U$ test was preferred in paired comparisons. As a result of the analyzes, it is seen that there are 5-1 and 4-1 telephone-internet sub-dimensions, 4-2 in parent visits sub-dimension and 4-2 in information-information sub-dimension.

The difference between the scores of the scores in terms of the gender argument was examined by Mann Whitney -U test and the results are given in Table 4.

Table 4: Mann Whithney-U test table in terms of gender variables (performing level)

\begin{tabular}{|c|c|c|c|c|}
\hline \multicolumn{2}{|l|}{ Gender } & $\mathbf{N}$ & Mean Rank & $\bar{Z}$ \\
\hline \multirow[t]{2}{*}{ Face to face $B$} & Man & 41 & 35,52 & \multirow{2}{*}{,- 01} \\
\hline & Woman & 29 & 35,47 & \\
\hline \multirow[t]{2}{*}{ Telephone B } & Man & 41 & 40,41 & \multirow{2}{*}{$-2,41 *$} \\
\hline & Woman & 29 & 28,55 & \\
\hline \multirow[t]{2}{*}{ Correspondence B } & Man & 41 & 37,96 & \multirow{2}{*}{$-1,20$} \\
\hline & Woman & 29 & 32,02 & \\
\hline \multirow[t]{2}{*}{ Visiting parents B } & Man & 41 & 39,55 & \multirow{2}{*}{$-1,99 *$} \\
\hline & Woman & 29 & 29,78 & \\
\hline \multirow[t]{2}{*}{ Home Visit B } & Man & 41 & 39,96 & \multirow{2}{*}{$-2,19 *$} \\
\hline & Woman & 29 & 29,19 & \\
\hline \multirow[t]{2}{*}{ Parent Meeting B } & Man & 41 & 35,02 & \multirow[b]{2}{*}{,- 23} \\
\hline & Woman & 29 & 36,17 & \\
\hline \multirow[t]{2}{*}{ Informed that B } & Man & 41 & 35,55 & \multirow{2}{*}{,- 02} \\
\hline & Woman & 29 & 35,43 & \\
\hline \multirow[t]{2}{*}{ Socialization B } & Man & 41 & 32,89 & \multirow{2}{*}{$-1,28$} \\
\hline & Woman & 29 & 39,19 & \\
\hline \multirow[t]{2}{*}{ Total B } & Man & 41 & 37,98 & \multirow{2}{*}{$-1,21$} \\
\hline & Woman & 29 & 32,00 & \\
\hline
\end{tabular}

When the scale scores were examined in terms of the phenomenon of performing the gender argument, a statistically significant difference was found in the sub-dimensions of telephone / internet, parent visits and home visits $(\mathrm{p}<0.05)$. When the averages are examined, it is seen that there are more realization levels in all three sub-men.

The difference between the status scale scores was examined by Kruskal Wallis test and the results are given in Table 5 .

Table 5: Kruskal Wallies test table in terms of education variables (performing level)

\begin{tabular}{lcccc}
\hline & Education & $\mathbf{N}$ & Mean Rank & Ki Square \\
\hline Face to face B & Ön lisans & 5 & 37,30 & \multirow{2}{*}{59} \\
& Lisans & 51 & 36,81 & \\
Telephone B & Lisansüstü & 14 & 30,07 & 20,60 \\
& Ön lisans & 5 & 32,80 & 36,79 \\
\hline
\end{tabular}


Gök, Y., \& Özen, G., (2019). Ways of communication between trainers and parents, Journal of Human Sciences, 16(4), 1207-1216. doi:10.14687/ihs.v16i4.5752

\begin{tabular}{|c|c|c|c|c|}
\hline \multirow[t]{3}{*}{ Correspondence B } & Ön lisans & 5 & 32,20 & \multirow{3}{*}{1,17} \\
\hline & Lisans & 51 & 34,45 & \\
\hline & Lisansüstü & 14 & 40,50 & \\
\hline \multirow[t]{3}{*}{ Visiting parents B } & Ön lisans & 5 & 48,90 & \multirow{3}{*}{11,21} \\
\hline & Lisans & 51 & 34,70 & \\
\hline & Lisansüstü & 14 & 33,64 & \\
\hline \multirow[t]{3}{*}{ Home Visit B } & Ön lisans & 5 & 16,80 & \multirow{3}{*}{5,92} \\
\hline & Lisans & 51 & 38,20 & \\
\hline & Lisansüstü & 14 & 32,36 & \\
\hline \multirow[t]{3}{*}{ Parent meeting B } & Ön lisans & 5 & 38,80 & \multirow{3}{*}{3,52} \\
\hline & Lisans & 51 & 33,95 & \\
\hline & Lisansüstü & 14 & 39,96 & \\
\hline \multirow[t]{3}{*}{ İnformed that B } & Ön lisans & 5 & 51,10 & \multirow{3}{*}{6,59} \\
\hline & Lisans & 51 & 33,06 & \\
\hline & Lisansüstü & 14 & 38,82 & \\
\hline \multirow[t]{3}{*}{ Socialization B } & Ön lisans & 5 & 41,00 & \multirow{3}{*}{1,14} \\
\hline & Lisans & 51 & 35,33 & \\
\hline & Lisansüstü & 14 & 34,14 & \\
\hline \multirow[t]{3}{*}{ Total B } & Ön lisans & 5 & 33,70 & \multirow{3}{*}{2,81} \\
\hline & Lisans & 51 & 35,25 & \\
\hline & Lisansüstü & 14 & 37,04 & \\
\hline
\end{tabular}

$$
{ }^{*} \mathrm{p}<0.05
$$

There was no statistically significant difference between the scale scores in terms of the realization of education independent variable $(\mathrm{p}>0.05)$.

Kruskal Wallies test was used to determine the difference between the scores of the scores of the scale of the coaching level and the results are given in Table 6.

Table 6: Kruskal Wallis test table in terms of coaching level (performing level)

\begin{tabular}{|c|c|c|c|c|}
\hline Coach seniority & & $\mathbf{N}$ & Mean Rank & Ki Square \\
\hline \multirow[t]{5}{*}{ Face to Face B } & 1.level & 7 & 32,00 & \multirow{5}{*}{1,27} \\
\hline & 2.level & 27 & 34,56 & \\
\hline & 3.level & 26 & 37,63 & \\
\hline & 4.level & 6 & 34,17 & \\
\hline & 5.level & 4 & 36,13 & \\
\hline \multirow[t]{5}{*}{ Telephone B } & 1.level & 7 & 19,00 & \multirow{5}{*}{$2,77^{*}$} \\
\hline & 2.level & 27 & 32,26 & \\
\hline & 3.level & 26 & 33,73 & \\
\hline & 4.level & 6 & 59,67 & \\
\hline & 5.level & 4 & 61,50 & \\
\hline \multirow[t]{5}{*}{ Correspondence B } & 1.level & 7 & 39,21 & \multirow{5}{*}{1,11} \\
\hline & 2.level & 27 & 35,91 & \\
\hline & 3.level & 26 & 33,73 & \\
\hline & 4.level & 6 & 40,83 & \\
\hline & 5.level & 4 & 29,75 & \\
\hline \multirow[t]{5}{*}{ Visiting parents B } & 1.level & 7 & 44,21 & \multirow{5}{*}{$2,39 *$} \\
\hline & 2.level & 27 & 31,46 & \\
\hline & 3.level & 26 & 30,88 & \\
\hline & 4.level & 6 & 56,33 & \\
\hline & 5.level & 4 & 46,25 & \\
\hline \multirow[t]{5}{*}{ Home Visit B } & 1.level & 7 & 45,71 & \multirow{5}{*}{, 78} \\
\hline & 2.level & 27 & 33,20 & \\
\hline & 3.level & 26 & 37,56 & \\
\hline & 4.level & 6 & 20,83 & \\
\hline & 5.level & 4 & 41,75 & \\
\hline \multirow[t]{5}{*}{ Visiting parents B } & 1.level & 7 & 38,71 & \multirow{5}{*}{1,11} \\
\hline & 2.level & 27 & 31,87 & \\
\hline & 3.level & 26 & 34,58 & \\
\hline & 4.level & 6 & 45,00 & \\
\hline & 5.level & 4 & 46,13 & \\
\hline
\end{tabular}


Gök, Y., \& Özen, G., (2019). Ways of communication between trainers and parents, Journal of Human Sciences, 16(4), 1207-1216. doi:10.14687/ihs.v16i4.5752

\begin{tabular}{|c|c|c|c|c|}
\hline \multirow[t]{5}{*}{ İnformed that B } & 1.level & 7 & 38,36 & \multirow{5}{*}{1,20} \\
\hline & 2.level & 27 & 33,76 & \\
\hline & 3.level & 26 & 31,46 & \\
\hline & 4.level & 6 & 53,33 & \\
\hline & 5.level & 4 & 41,75 & \\
\hline \multirow[t]{5}{*}{ Socialization B } & 1.level & 7 & 30,57 & \multirow{5}{*}{,43 } \\
\hline & 2.level & 27 & 37,02 & \\
\hline & 3.level & 26 & 34,37 & \\
\hline & 4.level & 6 & 41,00 & \\
\hline & 5.level & 4 & 33,00 & \\
\hline \multirow[t]{5}{*}{ Total B } & 1.level & 7 & 38,93 & \multirow{5}{*}{,12 } \\
\hline & 2.level & 27 & 32,76 & \\
\hline & 3.level & 26 & 34,44 & \\
\hline & 4.level & 6 & 47,33 & \\
\hline & 5.level & 4 & 37,13 & \\
\hline
\end{tabular}

When the scale scores were examined in terms of the phenomenon of performing the coaching seniority argument, there was a statistically significant difference between the subdimensions of telephone / internet and parent visits $(\mathrm{p}<0.05)$. In order to determine the difference between groups, Mann Whitney-U test was preferred in paired comparisons. As a result of the analyzes, it is seen that there are 5-1 and 4-1 sub-dimensions of telephone-internet sub-dimension and 4-2 of parental visits.

The co-operative t-test of the coaches was given the importance of the communication and realization condition, and the results are given in table 7 .

Table 7: The ways of communicating care and realization status paired $\mathrm{T}$ test table

\begin{tabular}{|c|c|c|c|c|}
\hline & & $\overline{\mathbf{x}}$ (mean) & SD & $\mathrm{t}$ \\
\hline \multirow[t]{2}{*}{ Pair 1} & Face to face & 16,38 & 2,16 & $5,69 *$ \\
\hline & Face to FaceB & 15,27 & 2,16 & \\
\hline \multirow[t]{2}{*}{ Pair 2} & Telephone & 22,08 & 3,06 & $5,71 *$ \\
\hline & TelephoneB & 20,02 & 3,99 & \\
\hline \multirow[t]{2}{*}{ Pair 3} & Correspondence & 58,38 & 7,15 & $10,20^{*}$ \\
\hline & Correspondence B & 49,30 & 8,93 & \\
\hline \multirow[t]{2}{*}{ Pair 4} & Visiting parents & 11,22 & 2,90 & $3,01 *$ \\
\hline & Visiting parents B & 10,42 & 2,96 & \\
\hline \multirow[t]{2}{*}{ Pair 5} & Home Visit & 9,75 & 2,78 & $6,30 *$ \\
\hline & Home Visit B & 8,00 & 3,16 & \\
\hline \multirow[t]{2}{*}{ Pair 6} & Visiting parents & 19,51 & 2,95 & $7,37 *$ \\
\hline & Visiting parents B & 17,60 & 3,83 & \\
\hline \multirow[t]{2}{*}{ Pair 7} & İnformed that & 8,04 & 1,38 & $2,55^{*}$ \\
\hline & Informed that B & 7,72 & 1,64 & \\
\hline \multirow[t]{2}{*}{ Pair 8} & Socialization & 30,40 & 4,83 & $6,61 *$ \\
\hline & Socialization B & 28,15 & 4,92 & \\
\hline \multirow[t]{2}{*}{ Pair 9} & Total & 175,80 & 16,15 & $11,71 *$ \\
\hline & Total B & 156,51 & 18,50 & \\
\hline
\end{tabular}

Table 7 shows a statistically significant difference in all sub-dimensions. When the arithmetic means are examined, it is seen that the level of care is higher in all sub-dimensions and the level of realization is lower. 


\section{Result and Discussion}

According to these results, it can be said that there is no communication between the coaches and the parents as much as the coaches want. According to the findings, socio-cultural activities of women, parent-visits of low-educated group, telephone-internet, parent-visits and information-informing ways of high level of education are more important.

The fact that women attach more importance to social activities in our country and that the importance of information and telephone technology is related to the level of education may have been effective in making such a result.

In terms of realizing the ways of communication, it is observed that men are better in the ways of telephone-internet, guardianship, home visits.

Considering the time and space comfort of men due to social structure, it is thought to have an effectonthisresult.It has been found that the higher the coaching seniority, the better the telephone-internet and parent visits.It is also seen in the findings that highly qualified coaches attach more importance to these sub-dimensions.

Considering that increasing coaching level means increasing both professional age and cognition level, it is thought that the comfort felt in the use of telephone and internet world and space which is increasingly spreading to our daily lives is effective in these results. However, when we look at the level of care and realization of communication ways, it is not seen that the sub-dimensions which are attributed more value in terms of gender and education level are realized more.In addition, it can be said that in all sub-dimensions, coaches do not achieve the level of realization as much as the value attributed to the ways of establishing relationships with parents.

This supports the assumption that the components that are considered to be important, but not necessary, are not made.In the study conducted by D'Angelo and Adler (1991) in order to reveal the importance of communication strategies, it was emphasized that effective communication techniques are communication established by using the opportunities of written communication and technology.In the study, it was also stated that teachers attached importance to face-to-face interviews.

Demirbulak (2000) stated that all participants (teachers, school principals, students) believe that interviews are necessary and that it is a good opportunity to obtain the most healthy information about the student through the face-to-face interview parents.According to Yildirım and Dönmez (2008), teacher-parent communication has an important role in the success of the student and the parent should be seen as an important part of the learning-teaching process.Based on this phenomenon, it will not be wrong to say that parent-teacher communication is one of the necessary components for success.

Cevat (2008) 's study revealed that the most preferred method for teachers to communicate with parents is individual interviews.Because of this, more time is devoted to the parents, the parent feels more comfortable and the children can express their problems more easily.Kaşıkç1 (1996), the results obtained in his study " 50\% of teachers find themselves inadequate to inform parents " finding is similar to our study.Aydemir (2008) stated that female parents have more communication with teachers in activities such as attending parent meetings, visiting school, and calling teachers home. The preference of an individual interview in communication with parents is stated as giving more time to the parents and expressing the problems of their children more easily, but the parents are becoming passive listeners (Yildirim and Dönmez, 2008). orientation may be the reason.Home visits; the environment is more comfortable and the athlete lives in terms of the environment has an important effect.

Smoll et al. (2011) emphasized that the coaching and the family is an important factor on the points of participation of young people in the participation and participation of the sport and the importance of bilateral communication for the optimum use of this factor. Hatzigeorgiadis and Biddle (2001) stated that positive communication and encouragement of the family with student-athlete had a positive effect on development and performance,on this 
framework, Erdner and Wright (2017) emphasized that their parents should be encouraged to communicate with athletes positively, helping them to dream for success. While all these stresses show the importance of communication between the sports instructor and the parents, the lack of communication at the desired level is significant.

In line with these results, it can be said that there is no communication between coaches and parents to the extent desired by coaches.

According to these results, it can be said that the coaches cannot perform as much as the value attributed to the parents. In addition, it can be said that women are more concerned with sociocultural activities than the ways of communication, the group with low level of education gives more importance to parents' meetings, while those with high levels of coaching tend to pay more attention to telephone, parent visits and informing-informing ways. In terms of the phenomenon of conducting communication paths, it is observed that males are better in telephone-internet, parental hierarchy and home-visit. It has also been found that telephone-internet and parent meeting paths are better performed as the seniority of coaching increases.

\section{Suggestions}

1. Organization of training seminars to describe the ways and importance of communication in order to close the difference between the importance attributed to the communication paths of the sports trainers and the level of achievement.

2. Conducting qualitative studies to determine the reasons for the difference between the importance attributed to the communication pathways and the level of achievement.

\section{References}

Aydemir, I. (2008), Parent Activities Affecting Student and Teacher Performance in Primary Education, Master Thesis, Yeditepe University, Institute of Social Sciences, Istanbul.

Çalık, C. (2007), The Role of School-Environment Relation in School Improvement: A Conceptual Analysis, Journal of Gazi University Education Faculty, 27(3):123-129.

Çamliyer, H., Çamliyer, H. (1998), Movement Education and Play in Children, İzmir: Can Ofset.

Ceyhan, E. (2008), Family Participation and Family Guidance in the Education Process. A.S. Türküm, (Ed.), Parents Education, Eskişehir: Anadolu University Open Education Publications, (153-176).

Coşkun, S.(2010), The Ways Of Communication With Parents Of Primary School Teachers. Master Thesis.

D'Agelo, D., Adler, R. (1991), A Catalyst for Improving Parent Involvement, Phd Delta Kappan, $72(5): 350-354$.

Demirbulak, D. (2000), A Study on Parent Teacher Interviews, National Education Journal, (146):53-55.

Ersanl, K. (1989), Fundamentals of Teacher-Student Relations in Secondary Education, Journal of Faculty of Education, Samsun: Ondokuz Mayıs University Faculty of Education Publication, 4: 40.

Erdner, S. M., \& Wright, C. N. (2017), The Relationship Between Family Communication Patterns and the Self-Efficacy of Student-Athletes, Communication \& Sport (3):368-389.

Güven, M., Güven, S. (2002), Perceptions and Guidance Requirements of Mothers with Children in Primary Education, Journal of Education for Life, 75: 56-59.

Hassle Frank L. Smoll, Sean P. Cumming, Ronald E. Smith, Enhancing. (2011), Coach-Parent Relationships in Youth Sports: Increasing Harmony and Minimizing International Journal of Sports, (6): 1.

Kaşıkçı, M. (1996), Opinions of Teachers on Their Qualifications in Cooperation with Parents in Primary Education, Unpublished Master's Thesis, Ankara University, Institute of Social Sciences, Ankara. 
Gök, Y., \& Özen, G., (2019). Ways of communication between trainers and parents, Journal of Human Sciences, 16(4), 1207-1216. doi:10.14687/ihs.v16i4.5752

Kolay, Y. (2004), The importance of school-family-environment cooperation in education system, National Education Journal, (164):94-104 .

Ludwig, D. (1991), Size and Timing of Metamorphosis in Complex Life Cycles: Time Constraints and Variation, by The Ecological Society of America, (2):413-427.

Lawson, M. A. (2003), School-family relations in context: parent and teacher perceptions of parent involvement, Urban Education, (38): 77-133.

Tutar, H. (2003), Organizational communication. Ankara: Seçkin Press.

Yildırım, C., Dönmez, B. (2008), A Study on School-Family Cooperation, Journal of Electronic Social Sciences, (23):98-115.

Yiğit, B. (2009), School-Community Relations and Social Participation, Turkish Education System and School Management Ed: Vehbi Çelik,Ankara: Pegem Publishing.

Hatzigeorgiadis, A., Biddle, S. J. H. (2001), Athletes' perceptions of how cognitive interference during competition influences concentration and effort, Anxiety, Stress and Coping (14):411-42. 